\title{
Katılımcı Bütçe Uygulamasının Etkinliği: Uşak il Özel İdaresi Örneği ${ }^{1 \bullet}$
}

\section{Effectiveness of Participatory Budget Implementation: The Case of Uşak Special Provincial Administration}

\section{Doç.Dr.Hatice Dayar ${ }^{2}$ - Mehmet Emin Uluten ${ }^{3}$}

Başvuru Tarihi: 04.10.2019

Kabul Tarihi: 30.12.2019

\section{Öz}

Globalleşme ve teknolojinin tüm dünyaya yayılması ile birlikte yönetim tarzlarında çeşitlilik kaçınılmaz olmuştur. Bütünleşen dünyada bireyler kendilerini yönetenleri sorgulamaya başlayarak her şeyin şeffaf olmasını istemektedir. 1980'li yıllarda Brezilya'da ortaya çıkan, 1990'li yıllarda gelişen, 2000'li yıllardan sonra tüm dünyada yayılmaya başlayan katılımcılık bütçeleme uygulamaları yönetimde halkında söz sahibi olmasına olanak vererek söz konusu harcamaların belirlenmesine imkan tanımaktadır.

Çalışmanın amacı katılımcı bütçeleme uygulamasının teorik çerçevesini ortaya koyduktan sonra, vaka çalışması kapsamında ele alınan Uşak İl Özel İdaresindeki etkinliğinin belirlenmesi için yapılan görüşme tekniği ile elde edilen veriler ışı̆̆ında içerik ve betimsel analizin yapılması amaçlanmaktadır. Çalışmadan elde edilen bulgular, katılımo bütçeleme uygulamasının halk tarafindan benimsendiği ve Uşak İl Özel İdarisinin etkinliğinin de pozitif olduğunu göstermektedir.

Anahtar Kelimeler: Katılımcılık, Katılımcı Bütçeleme, Yerel Yönetimler, Nitel Analiz

\section{Abstract}

With globalization and the spread of technology all over the world, diversity in management styles has become inevitable. In an integrated world, individuals begin to question those who govern themselves and want everything to be transparent. Participatory budgeting practices, which emerged in brazil in the 1980s, developed in the 1990s and started to spread all over the world

\footnotetext{
1 Hatice Dayar'ın danışmanlığında yürütülen ve Dumlupınar Üniversitesi Sosyal Bilimler Enstitüsü’nde savunulan ve kabul edilen yayınlanmamış ULUTEN, Mehmet Emin(2019), Katılımcı Bütçe Uygulamasının Etkinliği: Uşak İl Özel İdaresi Örneği, adlı yüksek lisans tezi veri alınarak hazırlanmıștır.

${ }^{2}$ Dumlupınar Üniversitesi, İİBF-Maliye Bölümü Öğretim Üyesi, hatice.dayar@dpu.edu.tr, ORCID: 0000-0002-1239-2895

${ }^{3}$ Dumlupınar Üniversitesi, İİBF-Maliye Bölümü Yüksek Lisans Mezunu, m.eminuluten@hotmail.com, ORCID: 0000-0003-1186-5125
} 
after the 2000s, enable the public to have a say in the management and allow the determination of these expenditures.

The aim of the study is to present the theoretical framework of participatory budgeting and to analyse the content and descriptive analysis in the light of the data obtained from the interview technique in order to determine its effectiveness in the Uşak Special Provincial Administration. The findings of the study show that the public adopts participatory budgeting and the effectiveness of Uşak Special Provincial Administration is positive.

Keywords: Participation, Participatory Budgeting, Local Governments, Qualitative Analysis

\section{Giriş}

Son yıllarda, halka açık süreçlere aktif katılım kavramının vatandaşlar tarafından benimsenmesi, katılımcı bütçe uygulamalarının yaygınlaşmasına neden olmuştur. Katılımcılık kavramı ve katılımcı bütçelemenin demokrasi anlayışı ve yönetişim ile ilişkisinin kurulması önem arz etmektedir. Katılımcı bütçeleme, temsili demokrasiden katılımcı demokrasiye geçiş sürecinde en önemli adımlardan biri olarak kabul edilmektedir. Katılımcı bütçelemede yerel hizmetlerin sağlanmasında yerel hizmetlerden ve yerel yönetimlerden yararlanan vatandaşlar ile yapısal bir ilişki kurulmaktadır. Bu yapısal ilişki, hem kamu hesap verebilirliğini sağlamak hem de yerel yönetimlerde kamu kontrolünü sağlamak için uygun bir ortam oluşturmaktır. Bu nedenle, katılımcı bütçelemenin yayılması, demokratik gelişme ve kaynak kullanımının etkinliğini sağlama açısından son derece önemlidir.

Çalışmada, katılımcı bütçelemenin kavramsal çerçevesi açıkladıktan sonra Uşak İl Özel İdarisinde uygulanan katılımcı bütçelemenin teorik ve ampirik yapısının analiz edilmesi amaçlanmıştır. Bunun için ilk olarak katılımcı bütçeleme ile ilgili teorik çerçeve ve uygulamalarla ilgili ulusal ve uluslararası bilimsel ve akademik çalışmalar taranmıştır. Bunun yanında daha sonra Uşak İl Özel İdaresi çalışanlarından görüşme tekniği vasıtasıyla veriler toplanarak, katılımcı bütçelemenin etkinliğinin ortaya konulması için veriler betimsel analiz yöntemleri ile çözümlenmiştir. Çalışmanın sonunda elde edilen bulgular çerçevesinde katılımcı bütçelemenin verimliliği ve etkinliğini arttırmak amacıyla önerilerde bulunulmuştur.

\section{Teorik Çerçeve}

Katılımcı bütçelemeyle ilgili ilk çalışmalar 1985 yılında, Brezilya'da, başlatılmış ve ilk kez bu ülkede uygulanmıştır. Günümüzde ise, Amerika kıtasında bulunan birçok ülkenin yanı sıra Asya, Avrupa ve Afrika'da 1200'den fazla şehir, katılımcı bütçe anlayışını kabul etmektedir. (Cabbanes, 2004, s. 29).

Katılımcılık, vatandaşların ve sivil toplum kuruluşlarının politika oluşturma, uygulama ve devletin denetim sürecine katılımını tanımlayan bir kavramdır. Katılımcılık, vatandaşların doğrudan veya temsil yolu ile karar alma ve yönetişime katılmalarıdır. Günümüzde, katılımcılık kavramı, yurttaş hakları, demokratik yönetişim, yolsuzlukla mücadele ve yoksulluğun 
azaltılması ile birlikte kullanılmaktadır. Katılımcı bütçe kavramı ise vatandaşların doğrudan dâhil oldukları ve kendilerini etkileyen bütçe yapılarını etkiledikleri süreç olarak ifade edilmektedir. Katılımcı bütçeleme; yönetime katılım, hesap verebilirlik, yerel yönetişim ve finansal şeffaflığı sağlamak için yeni bir yönetim anlayıșı olarak tanımlanmaktadır (Ergen, 2012, s. 319-324).

Katılımcı bütçeleme uygulamasında, vatandaşlar karar alma sürecine doğrudan dahil olduklarından, yıl boyunca birçok toplantı düzenlenmektedir; böylece vatandaşlar, kamu kaynaklarının nasıl kullanıldığını gözetleme, sosyal politikalar arasında seçim yapma ve kamu kaynaklarının tahsisinde öncelikler belirleyebilme imkânı söz konusudur. (Yalçın, 2015, s. 315). Genel olarak yerel yönetimlerin vatandaşların tercihlerini ve kamu hizmetlerinin maliyetini daha iyi bildiğine inanılmaktadır. Yerel yönetimlere daha fazla mali özerklik getiren mali merkezileşme, bölgesel rekabet edebilirliği ve vatandaşların siyasi katılımını arttırmaya yardımcı olmaktadır. $\mathrm{Bu}$, devlet davranışını sınırlamaya ve yönetişim etkinliğini arttırmaya yardımcı olmaktadır. Mali ademi merkeziyetçilik vatandaşlara karar alma yetkisi sağlayabilmektedir (Altıngöz Zarplı, 2017, s. 63).

\section{Literatür Incelemesi}

Katılımcı bütçeleme konusu ile ilgili ulusal ve uluslararası düzeyde akademik ve bilimsel çalışmaların olduğu görülmektedir. Yapılan çalışmalardan bazıları aşağıda özetlenmektedir.

Taytak (2019) çalışmasında, kamu üniversitelerinde katılımcı bütçe anlayışının uygulanabilirliğini belirlemeye çalışmıştır. Çalışmada nitel araştırma yöntemi kullanılmıştır. Öğrencilerle yapılan görüşmelerden elde edilen bulgular, katılımcı bütçe anlayışının üniversitelerde geçerli olduğu görülmüştür; bunun bir sonucu olarak, kurumlardaki iyi yönetişim ve katılımcı demokrasinin olumlu katkıda bulunabileceği sonucuna ulaşılmıştır.

Dağı (2017) çalışmasında yöneticilerin katılımcı bütçesine ilişkin davranış ve algılarını analiz etmektedir. Çalışmadan elde edilen bulgulara göre, katılımcı bütçenin uygulanabilirliğinin yöneticilerin davranış ve tutumlarına göre farkl11ık gösterebileceği bulunmuştur.

Altıngöz Zarplı (2017) doktora çalışmasında, birçok ülkede uygulanan katılımcı bütçeleme sürecini, farklı yöntemlerle göstermek ve belediyelerdeki uygulama veya uygulama denemelerine dayanarak göstermektedir. Yapılan araştırmanın sonucunda Türkiye'nin katılımcı bütçelemeyi yeni yeni tecrübe ettiği ve kamu yönetiminde katılımcı bütçeleme mekanizmalarını yeni kamu yönetimi reformu kapsamında uygulamaya başladığı bulgularına rastlanılmıştır.

TEPAV (2007) çalışmada iyi bir yönetişim için katılımcı bütçelemeyi incelemiştir. Çalışmada katılımcı bütçe uygulamasının kaynakların dağılımına odaklı denenmiş somut bir yönetişim uygulaması olduğu, etkin ve demokratik bir yönetim için katılımcı bütçenin tek başına çare olamayacağı ifade edilmiştir. Ayrıca yerel düzeyde hem yönetim hem sivil toplum örgütlerince sahiplenilerek uygulanması durumunda katılımcı bütçenin iyi yönetişimin hayata geçirilmesinde önemli katkısı olacağı sonucuna yer verilmiştir.

Özen ve Yontar (2009) çalışmasında, demokrasi ve demokrasinin finansal yansıması olan katılımcı bütçeleme hakkında bilgi vermektedir. Daha sonra, dünyada ve Türkiye'de katılımcı bütçe anlayışının ne düzeyde bir anlayışa sahip olmaya çalışmaya odaklanmıştır. Bu çalışmada, 
katılımcı bütçe anlayışının katılımcı demokrasinin kurulmasında önemli bir rol oynadığı neticesine varılmıştır.

Sakınç ve Aybarcı Bursalıoğlu (2014) yaptıkları makalede katılımcı bütçeleme uygulamalarını göz önüne alarak katılımcllar Türkiye için tecrübe ve bütçe modelinden kaynaklanan olanaklar incelenmiştir.Kkatılımcı bütçe uygulaması kapsamında vatandaş bazlı katılımın güçlendirilmesi dinamikleri ve yöntemleri hakkındaki literatür incelenmiştir. Katılımcı bütçe uygulamasının toplumsal strateji önceliklerini belirleme, daha kaliteli hizmetler üretme, yolsuzluğu azaltma ve şeffaflığı arttırmada çok önemli bir rol oynadığı neticesine varılmıştır.

Çobanoğulları ve Yereli (2017) çalışmalarında katılımcı demokrasi bağlamında katılımcı bütçelemeyi tartışmış ve katılımcı bütçeleme süreci hakkında bilgi vermiştir. Araştırmada, dünyadaki katılımcı bütçeleme örnekleri göz önüne alındığında, katılımcı bütçe uygulaması, kamu kaynaklarının verimli kullanılmasında, kaynakların tahsis edilmesinde, hizmetlerin sağlanmasında ve katılımcının güçlendirilmesinde şeffaflı̆̆ın artırılmasını sağlayan bir araç olduğu olgusuna ulaşılmıştır. Diğer taraftan, katılımcı bütçe uygulamasında vatandaşların ve diğer paydaşların sisteme ilk aşamada dahil edilmesi bir başarı ölçütü olarak sayılmıştır.

Gergerlioğlu ve Dibo (2017) tarafından yapılan çalışmada ise son zamanlarda yerel yönetimler özelinde katılımcı bütçeleme uygulamalarında olan ilerlemelerin, başka Avrupa ülkeleri ve Türkiye düzleminde incelenerek gereksinim olarak belirtilen katılımcı mekanizmaların benimsenmesi ve bu mekanizmaların kamusal harcama süreçlerine faal olarak katılımlarının olması gerektiği üzerinde durmuşlardır.

Sintomer vd. (2008, s. 164) çalışmada, Avrupa'daki katılımcı bütçelemeyi incelemektedir. Brezilya'dan Avrupa'ya katılımcı bütçelemenin "transferi" oldukça farklı bir süreç olmuştur. Avrupa için uyarlanmış Porto Alegre modelleriyle ve "üçlendirilmiş katılımcı bir yönetişimin" geliştirebileceği ve toplumun fon sağladığı ve üç klasik olanın ötesinde dördüncü bir gücün, yani doğrudan vatandaşın delegeler aracılığılya)bir karar alma gücü ön plana çıkmaktadır.

Cabannes (2004, s. 27) makalede, Brezilya'da ve başka yerlerde katılımcı bütçelemeyi demokrasi ve yerel kalkınmada önemli bir inovasyon alanı olarak tanımlamaktadır.

Souza, (2001, s. 159) araştırmada, Brezilya'daki katılımcı bütçelemeyi tanımlamaktadır. Brezilya'da bir kentin her bölgesindeki vatandaş meclisleri, kentin gelirlerinin bir kısmının kullanımı için öncelikleri belirlemektedir. Katılımcı bütçelemenin eskiden dışlanmış grupların topluluklarındaki yatırım öncelikleri hakkında karar vermelerine ve hükümeti izlemelerine nasıl izin verdiğini vurgulamaktadır.

Öte yandan Szescilo (2015), Polonya'da farklı büyüklükteki dokuz belediyede katılımcı bütçe uygulamasının sonuçlarını kapsamlı bir şekilde analiz etmiştir. Bu modelde, "katılımın yerel bütçenin küçük bir kısmı ile sınırlı olduğu ve stratejik konularda halkın görüşleri alındığı" belirtilmektedir.

\section{Araştırmanın Metodolojisi}

Çalışma çerçevesinde yürütülen saha araştırmasının amacı, araştırmada kullanılan veriler (veri toplama aracı), sınırlamalar, yöntemler ve bulgular başlıklar halinde listelenmiştir. Araştırmanın kapsamı, veri toplama aracındaki araştırmanın değişkenleri ve araştırmanın 
amacı gibi bilgileri tanımlayarak oluşturulmaktadır. Daha sonra araştırmadan elde edilen bulgular yorumlanmıştır.

\section{Araştırmanın Amacı}

Araştırma, Uşak İl Özel İdaresindeki katılımcı bütçe uygulamalarının etkinliğinin meydana çıkarılması amacıyla gerçekleştirilmiştir.

\section{Araştırmada Kullanılan Veriler ve Evreni}

Çalışmanın evreni Uşak İl Özel İdaresinde çalışan personelden ve örneklem 11 anketörden oluşmaktadır.

\section{Araştırmanın Sınırlılıkları}

Çalışma, 11 katılımcıdan oluşan bir örneklemin verdiği cevaplarla sınırlıdır. Örnekteki kısıtlama, tüm araştırma evrenini araştıramamaktır.

\section{Araştırmanın Yöntemi}

Çalışmada nitel veri tekniklerinden yarı yapılandırılmış görüşme tekniği uygulanmıştır. Yarı yapılandırılmış derinlemesine görüşme tekniği, teorik veya yöntem açısından açık bir yapıya sahip olan, genellikle röportajlar ve gözlemler içeren nitel yaklaşımları ifade etmek için kullanılmaktadır. Bu teknik görüşme soruları dışında ek sorular sorulmasına imkan tanıyan bir tekniktir. Bu açıdan araştırmacılara esneklik vermektedir (Blandford, 2013, s. 2).

\section{Verilerin Toplanması}

Çalışmanın verileri, katılımcıların kendilerini özgürce ifade edebildikleri sessiz bir ortamda gerçekleştirilmiş ve katılımcıların randevu aldığı dönemde ses kayıtları yapılmış ve görüşmeler yapılmıştır. Görüşme soruları her katılımcıya aynı kelimeler ve aynı anlamlarla yönlendirilmiştir. Uşak İl Özel İdaresi'nde çalışanlarla yapılan görüşmelerde ses kaydı ve not tutma tekniği tercih edilmiştir. Daha sonra ses kayıtları analiz edilmek ve analiz kolaylığı için yazılmıştır. Ses kayıtları ile yapılan görüşmelerin analizleri sonucunda her görüşmecinin ortalama 3 sayfa bulunduğu ve yaklaşık 30 sayfa veri toplandığı görülmüştür. İlk olarak, verilerin doğruluğu transkripsiyon ve transkriptlerin tutarlılığı kontrol edilmiştir. Daha sonra veriler belirlenen temalara göre değerlendirilmekte ve yorumlarda gerekli olduğu yerlerde doğrudan alıntı şeklinde yapılmıştır.

\section{Araştırmanın Etiği}

Gizlilik kurallarına göre katılımcıların isimleri, kimlik bilgileri vb. kullanılmamıştır. Araştırma kesinlikle herhangi bir adli ve idari kurum, organizasyon ve olayla ilgili olmayı, yalnızca bilimsel amaçlar için kullanılmaktadır.

\section{Mülakat Yapılan Kişilerin Özellikleri}

Çalışma, Uşak il özel idarisinde uygulanan katılımcı bütçelemenin etkinliğinin ortaya konulmasıdır. Bu kapsamda İl özel idaresinde çalışan 11 kişi ile yapılan mülakatta genel olarak katılımcı bütçe ile ilgili sorular sorulmasına karşın mülakat yapılanlar ile ilgili genel demografik nitelikler aşağıda verilen Tablo 1'de sunulmaktadır. 


\begin{tabular}{|c|c|c|c|c|c|}
\hline Görüşmeler & Cinsiyet & Yaş & $\begin{array}{l}\text { Eğitim } \\
\text { Düzeyi }\end{array}$ & Meslek & $\begin{array}{c}\text { En son Bitirdiği } \\
\text { Okul }\end{array}$ \\
\hline G1 & Kadın & 38 & Lisans & Şehir Plancisı & $\begin{array}{l}\text { Erciyes Üniversitesi } \\
\text { Mimarlık Fakültesi }\end{array}$ \\
\hline G2 & Erkek & 49 & Lisans & İGM Başkanı & Fakülte \\
\hline G3 & Erkek & 65 & Lisans & $\begin{array}{c}\text { Plan-Proje } \\
\text { Şube Müdürü }\end{array}$ & $\begin{array}{c}\text { Isparta Süleyman } \\
\text { Demirel Üniversitesi }\end{array}$ \\
\hline G4 & Erkek & 60 & Lisans & $\begin{array}{l}\text { Encümen Üyesi } \\
\text { Türkçe }\end{array}$ & $\begin{array}{l}\text { Uşak Eğitim } \\
\text { Enstitüsü }\end{array}$ \\
\hline G5 & Erkek & 50 & Lisans & $\begin{array}{c}\text { IGM Başkan } \\
\text { Yrd. }\end{array}$ & $\begin{array}{c}\text { Ankara Üniversitesi } \\
\text { Ziraat Fakültesi }\end{array}$ \\
\hline G6 & Kadın & 32 & Lisans & Bütçe Servisi & Anadolu Üniversitesi \\
\hline G7 & Kadın & 30 & $\begin{array}{l}\text { Yüksek } \\
\text { Lisans }\end{array}$ & Bütçe Planlama & $\begin{array}{c}\text { Uşak Üniversitesi } \\
\text { Sosyal Bilimler }\end{array}$ \\
\hline G8 & Erkek & 46 & Lisans & $\begin{array}{l}\text { D1ş İlişkiler } \\
\text { Müdürü }\end{array}$ & $\begin{array}{l}\text { Uşak Eğitim } \\
\text { Enstitüsü }\end{array}$ \\
\hline G9 & Erkek & 33 & Lisans & $\begin{array}{l}\text { Mali Hizmetler } \\
\text { Müdür Vekili }\end{array}$ & $\begin{array}{c}\text { Uşak } \\
\text { Üniversitesi }\end{array}$ \\
\hline G10 & Erkek & 32 & Lisans & Bütçe Servisi & Uşak Üniversitesi \\
\hline G11 & Kadın & 46 & Ön Lisans & Bütçe Planlama & Anadolu Üniversitesi \\
\hline
\end{tabular}

Görüşmeye katılan 11 kişiden 7 tanesi erkek iken, 4 tanesi bayandır. Katılımcıların hemen hemen hepsi lisans mezunudur ve yalnızca 1 tane ön lisans mezunu olduğunu beyan etmiştir.

İl özel idarede genellikle bütçe servisinde çalışan katılımcılar çeşitli üniversitelerin muhtelif bölümlerinden mezun oldukları görülmektedir.

\section{Istatiksel Yöntem}

Araştırmanın analizinde, elde edilen röportaj yanıtlarına göre betimsel ve içerik analizi metotları tercih edilmiştir. Sonrasında ise sorulara verilen cevaplar betimsel ve içerik analizi uygulanarak yorumlanmıştır.

Betimsel Analiz, Betimsel analiz, ürünler, insanlar, bireyler, olaylar ve durumlarla ilgili verilerin toplanmasını ve ardından sonucu organize etmeyi, çizelgelemeyi, tasvir etmeyi ve tanımlamayı içerir. Betimsel analizin temel özellikleri, araştırmacıların değişkenler üzerinde kontrol sahibi olmamasıdır, sadece ne olduğunu veya şu anda neler olduğunu rapor edebilmesidir. Betimsel araştırmalarda yaygın olarak kullanılan metodolojiler her türlü anket ve mülakattır; (Baha, 2016, s. 4). Bununla birlikte betimsel analiz dört kademeden oluşmaktadır (Altıngöz Zarplı, 2017, s. 116; Yıldırım ve Şimşek, 2016, s. 240).

İçerik Analiz, Öncelikli olarak kantitatif bir araştırma yöntemi olarak kullanılmış, metin verileri açık kategorilere kodlanmış ve istatistikler kullanılarak yazılmıştır. Bu yaklaşım bazen nitel verilerin nicelleştirmesi olarak da adlandırılmaktadır (Hsieh ve Shannon, 2005, s. 1278). 


\section{Araştırmanın Bulguları ve Değerlendirilmesi}

Görüşmeye katılan fertlerin düşünceleri söz konusu temalar çerçevesinde; gizlilik kaidesi çerçevesinde, adları verilmeden kodlanarak nakledilmektedir. Yukarıda da söylendiği gibi her bir katılımcı ile yapılan görüşme "görüşme” yi temsil ettiği için " $G$ ” şeklinde kodlar verilerek ve her görüşmeye katılan kişiler düzenli olarak kodunun yanında "G1, G2, G3......G10” biçiminde kodlamalar kullanılmıştır.

Derinlemesine röportaj kapsamında katılımcılara 9 soru sorulmuştur. İlk üç soru katılımcı bütçe ile ilgili sorular olup, bu sorular katılımcı bütçe uygulamasına karşı algılarını ölçmeye yöneliktir. Diğer sorular ise İl özel idaresindeki uygulamaların nasıl ve etkinliğinin belirlenmesine yönelik sorulardır. Mülakat ile elde edilen veriler değerlendirilmesi için her soru tek tek ele alınmaktadır.

\section{Soru 1: Katılımcı Bütçe uygulaması nedir?}

İlk soru görüşmeye katılanların katılımcı bütçeyi nasıl tanımladıkları üzerinedir ve aşağıda verilen Tablo 2'de verilen cevaplar yer almaktadır.

Tablo 2. Katılımcı Bütçe Uygulaması Nedir? 


\begin{tabular}{|c|c|}
\hline $\begin{array}{l}\text { Katılımci } \\
\text { Kodu }\end{array}$ & Katılımcı Cevabı \\
\hline G1 & $\begin{array}{l}\text { Halkın talep ve isteklerinin dikkate alındığı demokratik bir bütçedir. Örnek vermek } \\
\text { gerekirse; ilk demokrasinin öne çıtığı gibi Antik Yunan'da bir yere toplanıp alının } \\
\text { kararlar gerçek demokrasidir. Peki, biz ne yapıyoruz seçimimizi birileri tarafından } \\
\text { yapıyoruz. Onlarda bizi temsil ediyor ama ne yazık ki talep ve isteklerimiz buraya } \\
\text { iletilemiyor. }\end{array}$ \\
\hline G2 & $\begin{array}{l}\text { Bana göre Katılımcı Bütçe ile ilgili en somut örneği olan kurumlar İl Özel İdarelerdir. } \\
\text { Çünkü bizlerin çok çeşitli görev ve yetkileri vardır. Bunlarında ağırlıklı kısmı şu an } \\
\text { yerelde hizmet veren köylerdir. Bu yüzden İl Özel İdare olarak hizmetlerimiz daha çok } \\
\text { kırsal kesime, özellikle de köylere yönelik hizmetlerdir. Bu hizmetlerde muhtarların } \\
\text { etkin bir rolü bulunmaktadır. Muhtarlar vasıstasıly halkın talep ve istekleri yerinde } \\
\text { dinlenilip buna yönelik bütçe oluşturulmaya özen gösterilmekte ve çalışmalar } \\
\text { yürütülmektedir özetle halkıng gerçek ihtiyaçlarına göre bir bütçe belirlenmektedir. Bizim } \\
\text { katıllımcı bütçeden anladığımız şey de budur. Yani katıllmcı bütçe, bütçe kalemlerinin } \\
\text { halkın isteklerinin bizzat yerinde tespit edilip müzakere edilmesi sonucunda } \\
\text { oluşturulmaktadır. }\end{array}$ \\
\hline G3 & $\begin{array}{l}\text { İlin yatırım çalışmalarının halk ve sivil toplum kuruluşlarının görüşlerinin alınarak } \\
\text { hazırlandığı bir bütçedir. }\end{array}$ \\
\hline G4 & $\begin{array}{l}\text { Toplumun ihtiyaçlarının belirlenmesi, planlanma yapılmas1 gereken ortak projelerin } \\
\text { mutlaka öncelikli olmasıdır. }\end{array}$ \\
\hline G5 & $\begin{array}{l}\text { Yapılacak olan hizmet ve yatırımların vatandaş-devlet işbirliği ile birlikte yerine } \\
\text { getirilmesini sağlayan bütçe uygulamasıdır. }\end{array}$ \\
\hline G6 & $\begin{array}{l}\text { İldeki vatandaşların ve STK'lerin yerel yönetim bütçe hazırlığından görüşlerinin alınarak } \\
\text { bütçe hazırlanmasıdır. }\end{array}$ \\
\hline G7 & $\begin{array}{l}\text { Yapılacak olan harcamalara ve hizmeteler bizzat vatandaş tarafından karar verilmesidir. } \\
\text { Hizmet verilen vatandaşın parasının nereye harcanacağı hususunda karar verebilmesi } \\
\text { için gerçek bir imkan sunmaktadır. }\end{array}$ \\
\hline G8 & $\begin{array}{l}\text { Bütçenin paydaşları ve etkilenenleri ile etkileşime girerek fikirleri doğrultusunda } \\
\text { bütçenin olușturulmasıdır. }\end{array}$ \\
\hline G9 & $\begin{array}{l}\text { Yerel yönetimlerde halkın katılımı ve beklediği hizmetler doğrultusunda oluşturulan } \\
\text { bütçedir. }\end{array}$ \\
\hline G10 & $\begin{array}{l}\text { Yerel yönetimlerde bütçe belirlenmesi aşamasında halkın istek ve beklentilerinin dikkate } \\
\text { alınması demektir }\end{array}$ \\
\hline G11 & $\begin{array}{l}\text { Kaynakların verimli bir şekilde kullanılabilmesi için hazırlanmış bir bütçe olduğunu } \\
\text { düşünüyorum. Bu şekilde hizmeti alan ve veren ortak çalışırsa daha faydalı hizmetler } \\
\text { yapılacaktır }\end{array}$ \\
\hline
\end{tabular}

Katılımcıların çoğunluğu katılımcı bütçeyi bilmektedir ama birkaç tanımlamada vatandaş veya halk yerine STK'ların yerel yönetim bütçelemede görüşlerinin alınması demişlerdir.

\section{Soru 2: Katılımcı Bütçe neden uygulanmalıdır?}

İkinci soru görüşmeye katılanların katılımcı bütçeyi neden uygulanması gerektiğine dair görüşleri alınmak istenmiştir ve aşağıda verilen Tablo 3'de verilen cevaplar yer almaktadır.

Tablo 3. Katılımcı Bütçe Neden Uygulanmalıdır?

\begin{tabular}{|cc|}
\hline $\begin{array}{c}\text { Katılımcı } \\
\text { Kodu }\end{array}$ & Katılımcı Cevabı \\
\hline
\end{tabular}




\begin{tabular}{|c|c|}
\hline G1 & $\begin{array}{l}\text { Kırsalı geliştirmek için öncelikli hizmetlerin tespiti gerekir. Bütçe } \\
\text { kaynaklarının doğru yere harcanması için önemlidir. Şöyle ki; İnsanların } \\
\text { yaşadığı yere ait ihtiyaçları vardır. Her yerin ihtiyacı da yaşadığı bölgeye } \\
\text { göre değişir. Her köyün talep ve istekleri farklıdır. Bunları yerinde tespit } \\
\text { edip yerinde çözüm bulunması gerekmektedir. }\end{array}$ \\
\hline G2 & $\begin{array}{l}\text { Öncelikle gerçek ihtiyaçların ortaya çlkarılması ve bu noktada bütçe } \\
\text { kaynaklarının etkin ve verimli kullanılabilmesi için halkın taleplerinin } \\
\text { dikkate alınması gerekir. Vatandaşların talebi olmadan bir yatırım } \\
\text { yapılması kaynakların verimsiz bir şekilde harcanmasına neden olur. } \\
\text { Kısaca; vatandaş isteklerinin dikkate alınıp harcama önceliklerinin yerinde } \\
\text { tespit edilmesi amacıyla katılımcı bütçe uygulanmalıdır. }\end{array}$ \\
\hline G3 & $\begin{array}{l}\text { Geniş bir kitleye daha faydalı hizmetler sunulabilmesi açısından katılımcı } \\
\text { bütçe uygulanmalıdır. Vatandaşın talebi ne ise o yapılmalıdır. }\end{array}$ \\
\hline G4 & $\begin{array}{l}\text { Ortak aklın oluşması, milletin gelirlerinin tabana daha adil ve eşit dağılması } \\
\text { için katılımcı bütçe uygulanmalıdır. }\end{array}$ \\
\hline G5 & $\begin{array}{l}\text { Temelde hizmetin vatandaşlarca sahiplenilmesi gereksiz harcamaların } \\
\text { önüne geçilmesi ve kamudaki israfın önlenmesi amacıyla Katılımcı } \\
\text { Bütçeleme uygulanmalıdır. }\end{array}$ \\
\hline G6 & $\begin{array}{l}\text { Katılımcı Bütçe demokrasisinin güçlenmesine katkı sağlar. Vatandaşların } \\
\text { yatırımları sahiplenip, korumasını teşvik eder. }\end{array}$ \\
\hline G7 & $\begin{array}{l}\text { Mahalle hakkının sorunlarına birebir çözüm imkanı sunacağından } \\
\text { katılımcı bütçenin uygulanması oldukça önemlidir. }\end{array}$ \\
\hline G8 & $\begin{array}{l}\text { Bütçenin daha verimli kullanılabilmesi ve daha gerçekçi olabilmesi için } \\
\text { katılımcı bütçeleme yapılmalıdır. Ayrıca bütçeden maksimum etki olmak } \\
\text { istiyorsak paydaşların ve etkilenenlerin fikirlerinin alınması gerekiyor. }\end{array}$ \\
\hline G9 & $\begin{array}{l}\text { Sinırlı kaynaklarla daha verimli hizmet ve projeler yürütmek için Katılımcı } \\
\text { Bütçe uygulamalıdır. }\end{array}$ \\
\hline G10 & Öncelikli hizmetler gerçekleşmiş olur. \\
\hline G11 & $\begin{array}{l}\text { Kurumların amacı halkın ihtiyaçlarını karşılamak olduğu için bütçe } \\
\text { çalışmalarında halkın önceliklerinin dikkate alınması gerekir. Bu yüzden } \\
\text { katılımcı bütçe uygulanmalıdır. }\end{array}$ \\
\hline
\end{tabular}

Katılımcı bütçenin uygulama gerekliliği olarak, öncelikli ihtiyaçların belirlenmesi, sınırlı kaynaklarla etkin hizmet verebilmek, yörenin/bölgenin/mahallenin isteklerine cevap verebilme ve faydalı hizmetler seklinde cevaplar verilmiştir. Farklı olarak G6 kişisi demokrasiye vurgu yapmıştır ve demokrasinin bir gereği olarak Katılımcı bütçenin uygulanmasına dikkat çekmektedir.

Soru 3: Katılımcı Bütçe uygulamasını daha önce duydunuz mu? 
Üçüncü soru ise görüşmeye katılanların katılımcı bütçe uygulamasını kurumlarında uygulamaya başlanılmadan önce duyup duymadıklarına dairdir ve aşağıda verilen Tablo 4'de verilen cevaplar yer almaktadır.

Tablo 4. Katılımcı Bütçe Uygulamasını Daha Önce Duydunuz Mu?

\begin{tabular}{|c|c|}
\hline $\begin{array}{c}\text { Katılımcı } \\
\text { Kodu }\end{array}$ & Katılımcı Cevabı \\
\hline G1 & $\begin{array}{l}\text { Daha önce duymadım. Ancak yurtdışında yerel yönetimlerin birlikte hareket } \\
\text { ettiklerini biliyorum. }\end{array}$ \\
\hline G2 & $\begin{array}{l}\text { Hayır duymadım, ama aslında biz yapmış olduğumuz hizmetlerde doğrudan } \\
\text { köy halkının ve muhtarların talepleri doğrultusunda yerinde ve } \\
\text { kurumumuzun imkanları dahilinde hizmetler gerçekleştirmekteyiz. Bu } \\
\text { anlamda Uşak İl Özel İdaresi olarak yapmış olduğumuz hizmetler bir nevi } \\
\text { katılımcı bütçe uygulamasına benzer faaliyetlerdir. }\end{array}$ \\
\hline G3 & $\begin{array}{l}\text { Evet. Sivil Toplum Kuruluşlarının katılımcı bütçe ile ilgili seminerlerine } \\
\text { katıldım. AB uygulamasıdır. }\end{array}$ \\
\hline G4 & $\begin{array}{l}\text { Uygulamada hep uyguladığımız projeler ama adını ilk kez duydum. Ama } \\
\text { sahada köy toplantılarında muhtarlıklarda yaptığımız faaliyetler özünü } \\
\text { oluşturuyor. }\end{array}$ \\
\hline G5 & $\begin{array}{l}\text { Evet, Son zamanlarda yerel yönetimlerde katılımcı bütçe uygulamasına } \\
\text { yönelik yapılan çalışmalardan haberim var. Geçmiş dönemde (2007) Uşak İl } \\
\text { Özel İdaresince katılımcı bütçe uygulamasına yönelik çalışmalar yapıldığını } \\
\text { köy ve mahalle muhtarlarından duydum. }\end{array}$ \\
\hline G6 & $\begin{array}{l}\text { Evet, daha önce uşak il özel idaresinde yerel yönetimlere destek reformu } \\
\text { kapsamında proje ili seçilen uşakta gerçekleştirilen katılımcı bütçe } \\
\text { çalışmasından haberdarım. }\end{array}$ \\
\hline G7 & Geçmiş yıllarda idaremizde de böyle bir uygulama yapılmaya çalışılmıştır. \\
\hline G8 & $\begin{array}{l}\text { Evet: Katılımcı Bütçe uygulaması hakkına bilgi sahibiyim. Uşak İl Özel } \\
\text { İdaresinde } 2007 \text { yılında yapılan çalışmalarda yer aldım. } 2007 \text { yılında Yerel } \\
\text { Yönetimlere Destek Projesi kapsamında Uşak ili pilot il seçilmiş ve Uşak İl } \\
\text { Özel İdaresinde katılımcı bütçe çalı̧maları, eğitim ve konferanslar } \\
\text { yapılmıştır. Bu çalışmalar arasında vatandaş memnuniyet Anketleri, Yerel } \\
\text { Hizmetlerin iyileştirilmesi amacıyla Eylem Planlarının hazırlanması, Yatırım } \\
\text { Karnesi, Çok yıllı yatırım programlaması ve çok yılı bütçe çalışmalarının } \\
\text { geliştirilmesi yer almaktadır. }\end{array}$ \\
\hline G9 & $\begin{array}{l}\text { Evet; Bu konuda bilgi sahibiyim. } 2007 \text { yılında Uşak İl Özel İdaresinde } \\
\text { Katılımcı Bütçe çalışmalarında yer aldım. Bu çalışmalarda vatandaş } \\
\text { memnuniyet anketleri ve yatırım kartları uygulamasına yer verilmiştir. }\end{array}$ \\
\hline G10 & Hayır \\
\hline G11 & ce duydum. \\
\hline
\end{tabular}

Bu soruya 11 görüşmeye katılanlardan sadece 4 tanesi bu uygulamayı duymadığını belirtmiştir. Genel olarak farkındalık fazladır, il özel idaresinde çalışanlar bu uygulamayı bilmeleri, uygulamada çok zorlanmadıkları sonucuna ulaşılması gerekmektedir.

\section{Soru 4:Uşak İl Özel İdaresi Katılımcı Bütçeye dair faaliyetler gerçekleştiriyor mu?}

Dördüncü soru ile birlikte Uşak İl özel idarisinde uygulanan katılımcı bütçe uygulamaları ile ilgili sorular sorulmaya başlanılmıştır. Bu sorular ile il özel idarede çalışanlardan bu kapsamda 
yapılan uygulamalar ve uygulamaların etkinliği konusunda bilgi almak hedeflenmiştir. $\mathrm{Bu}$ soruya verilen cevaplar ise Tablo 5'de gösterilmektedir.

\section{Tablo 5. Uşak İl Özel İdaresi Katılımcı Bütçeye Dair Faaliyetler Gerçekleştiriyor Mu?}

\begin{tabular}{|c|c|}
\hline $\begin{array}{l}\text { Katılımcı } \\
\text { Kodu }\end{array}$ & Katılımcı Cevabı \\
\hline G1 & $\begin{array}{l}\text { Encümen üyeleri ve Muhtarlar aracıllğıyla katılımcı bütçe faaliyetleri } \\
\text { gerçekleștiriliyor. Doğrudan vatandaş talepli hizmetler imar müdürlüğünce } \\
\text { yapıllyor. Çünkü biz vatandaşın kendi parseli üzerindeki yatırımların takibini } \\
\text { yapıyoruz. Örneğin siz akaryakıt istasyonu yapmak istiyorsunuz. Biz bunu } \\
\text { kurumlara sorarak araştırmasını yapıyoruz. İmar planlarını hazırlatıp meclise } \\
\text { sunuyoruz. }\end{array}$ \\
\hline G2 & $\begin{array}{l}\text { Bizim çalışmalarımız şu şekildedir: Halkın taleplerini alıyoruz ve yerinde } \\
\text { inceliyoruz. Onlara belli bir mutabakata varıyoruz. Önümüzdeki bütçede de } \\
\text { bunlar için bir kaynak ayırıyoruz. Başka bir ifade ile halkın taleplerini bizzat } \\
\text { yerinde inceliyoruz. Ve hangi yatırıma ihtiyaç var ise bunu tespit ediyoruz. }\end{array}$ \\
\hline G3 & $\begin{array}{l}\text { Kısmen; Uşak İl Özel İdaresi daha çok Muhtarlar aracıllŏıyla ve köy halkının } \\
\text { talepleri doğrultusunda katılımcı bütçeye dair faaliyetler gerçekleştiriyor. Köy } \\
\text { muhtarları ile yapılan toplantılarda köy halkının istek ve talepleri } \\
\text { değerlendirilmektedir. }\end{array}$ \\
\hline G4 & $\begin{array}{l}\text { Elbette Kendi İlçesinde (Eşme) } 59 \text { köyün tamamında köy kahvesinde halkın } \\
\text { huzurunda muhtarlardan bir sonraki yılın yatırım ihtiyaçlarını tartışarak } \\
\text { önceliğini belirleyerek tespit ediliyor. }\end{array}$ \\
\hline G5 & $\begin{array}{l}\text { Evet, İl Özel idare olarak daha çok köylere yönelik yapılan hizmet ve yatırımlar } \\
\text { bu kapsamda değerlendirilebilir. (Örneğin; İl özel idare araç ve gereçlerinin } \\
\text { köylülerin talepleri doğrultusunda kullanılması, Köylere yönelik yapılacak } \\
\text { hizmet ve yatırım taleplerinin köy muhtarları aracılığıyla toplanması) }\end{array}$ \\
\hline G6 & $\begin{array}{l}\text { Stratejik plan hazırlanırken paydaş görüşleri alınarak, bütçe hazırlı̆̆ } \\
\text { aşamasında bu görüşlerde göz önünde bulundurulmaktadır. }\end{array}$ \\
\hline G7 & $\begin{array}{l}\text { Uşak İl Özel İdaresinde de genelde muhtarların aracıllı̆̆ ve talepler } \\
\text { doğrultusunda katılımın geniş olduğu bir bütçe yapılmaya çalışılmaktadır. }\end{array}$ \\
\hline G8 & $\begin{array}{l}\text { Evet, şundaki yapılan çalışmalar } 2007 \text { yılında il özel idaresinde denenen } \\
\text { katılımcı bütçe uygulamasını kısmen devamı niteliğinde olup, Stratejik Palanda } \\
\text { içi ve dış paydaş analizine yer verilerek paydaşlar belirlenmekte ve katılıma } \\
\text { teşvik edilmektedir. Bu kapsamda bütçe yaparken yatırım kartları ile } \\
\text { paydaşların taleplerini alıyoruz. Muhtarlar ile yapılan toplantılar ile kırsal } \\
\text { kesimin (köy halkının) talep ve istekleri muhtar talep formaları ile alınmakta } \\
\text { Encümen ve İl Genel Meclisi üyeleri tarafından köylerde toplantırar } \\
\text { düzenlenmekte öncelikli hizmet ve yatırımlar yerinde tespit edilerek önem } \\
\text { derecesine göre yatırımcı müdürlüklerimiz tarafından değerlendirilip, } \\
\text { Encümen ve İl Genel Meclisinde görüşüldükten sonra bütçeleme yapmaktayız. }\end{array}$ \\
\hline G9 & $\begin{array}{l}\text { Uşak İl Özel idaresi Katılımcı Bütçe uygulamaya yönelik Muhtar Talepleri ve } \\
\text { Encümen Üyelerinin talepleri doğrultusunda paydaş kurumların talepleri } \\
\text { alınmakta ve katılımcı bütçeye yönelik çalışmalar yapılmaktadır. }\end{array}$ \\
\hline G10 & Kismen \\
\hline G11 & $\begin{array}{l}\text { Uşak İl Özel İdaresi bütçenin hazırlanması aşamasında kısmen bile olsa } \\
\text { katılımcı bütçeye dair faaliyetler gerçekleştirmektedir. }\end{array}$ \\
\hline
\end{tabular}

Bu soruya görüşmeye katılan 11 kişiden, 3’ü uygulamanın kısmen olduğunu belirtmişlerdir. Katılımcı bütçenin paydaşların görüşleri alınarak hazırlandığını beyan etmiştir. 2007 yılında 
uygulanan katılımcı bütçenin verimli olduğunu, şuanda olan uygulananında devamı niteliğindedir.

\section{Soru 5: Uşak İl Özel İdaresi Katılımcı Bütçe uygulamasına yönelik nasıl bir strateji izlemektedir?}

Beşinci soru ile birlikte Uşak İl özel idarisinde katılımcı bütçe uygulamalarında nasıl bir strateji izlendiği sorulmuştur. Bu soru ile il özel idarenin bu uygulamaya planlı bir şekilde stratejiler belirleyerek mi uygulamaya başladığ 1 veya uygularken $\mathrm{mi}$ bu sistemi öğrendikleri irdelenmektedir. Bu soruya verilen cevaplar ise Tablo 6'de gösterilmektedir.

\section{Tablo 6. Uşak İl Özel İdaresi Katılımcı Bütçe Uygulamasına Yönelik Nasıl Bir Strateji İzlemektedir?}

\begin{tabular}{|c|c|}
\hline $\begin{array}{c}\text { Katılımcı } \\
\text { Kodu }\end{array}$ & Katılımcı Cevabı \\
\hline G1 & $\begin{array}{l}\text { Birinci önceliğimiz yol hizmetleri, su, kanal hizmetleri asıl ihtiyaçlar } \\
\text { belirleniyor programa alınıyor ama bütçe tasarlanırken politik baskıdan } \\
\text { dolayı araya ikinci öncelikli yatırımlar giriyor. Şöyle sorunlarla da } \\
\text { karşılaşıyoruz; çocuk oyun alanını her köye yapıyoruz. Biz bunu köyler arası } \\
\text { haksızlık olmaması için yapıyoruz. Fakat hiçbir çocuğun olmadığı köylerin de } \\
\text { bunu istemesi gerçekten ihtiyacı olacak yatırımların önüne geçiyor ve bütçe } \\
\text { boşuna harcanmışoluyor. }\end{array}$ \\
\hline G2 & $\begin{array}{l}\text { Bu konuda İdare olarak izlediğimiz strateji sahada ve yerinde vatandaşı } \\
\text { dinliyoruz, teknik ekipler ile de yerinde inceleme yaparak vatandaş odaklı bir } \\
\text { çalışma yapıyoruz. Ayrıca köylerde muhtarlar toplantısı yapmaktayız ve } \\
\text { onlarla sözlü istişareler yaparak yapılacak hizmet ve yatırımlar konusunda } \\
\text { muhtarlardan yazılı talep formları almaktayız. Muhtar taleplerinin } \\
\text { gerçekleşme olasılığı şu şekildedir; yapılacak hizmet ve yatırımlar yerinde } \\
\text { değerlendirerek sürdürebilirlik açısından fayda maliyet analizine tabi } \\
\text { tutulduktan sonra uygunsa bütçemizde değerlendirme noktasında karara } \\
\text { varıyoruz. }\end{array}$ \\
\hline G3 & $\begin{array}{l}\text { Genelde bütçe oluşturma sürecinde paydaş olarak belirlenen kurum ve } \\
\text { STK'ler ile diyalog kurularak ve toplantılar yapılarak görüşleri alınıyor. Bu } \\
\text { doğrultuda hizmet yatırım ve projeler öncelik ve önem sırasına göre yerine } \\
\text { getirilmektedir. Örneğin; ilimizde okullarında inşasında STK'lerin görüşleri } \\
\text { alınıyor. }\end{array}$ \\
\hline G4 & $\begin{array}{l}\text { Özel İdare kırsalı esas alıyor. Öncelik sayıyor. Kırsalın kalkınması için refah } \\
\text { seviyesini yükseltici proje ve strateji izlemektedir. }\end{array}$ \\
\hline G5 & $\begin{array}{l}\text { Köylerin ihtiyaçlarının belirlenmesi amacıyla daha çok köy muhtarları ile } \\
\text { görüşme ve toplantılar yapılmakta, yapılacak olan hizmet ve yatırımların } \\
\text { öncelikleri tespit edilip İl Özel İdaresi bütçesi ile entegre ediliyor. Encümen } \\
\text { ve İl Genel Meclisi toplantılarında vatandaş talepli hizmetler öncelikli olarak } \\
\text { ele alınmakta hizmet-yatırım önceliği ve önemine göre ve özel idarenin mali } \\
\text { imkanları çerçevesinde bütçeleme yapılmaktadır. Stratejik planlarda paydas } \\
\text { analizine yer verilerek bütçeleme süresince ortak aklın oluşmasına özen } \\
\text { gösterilmektedir. Yatırım kartları uygulaması yoluyla kurumların ihtiyaçları } \\
\text { belirlenmekte yatırımların doğru bir şekilde belirlenmesi ve kamu } \\
\text { kaynaklarının daha etkin ve verimli kullanılması için }\end{array}$ \\
\hline
\end{tabular}




\begin{tabular}{|c|c|}
\hline & $\begin{array}{l}\text { önceliklendirilmektedir. Burada yapılacak hizmet ve yatırımın fayda ve } \\
\text { maliyeti göz önünde bulundurulmaktadır. }\end{array}$ \\
\hline G6 & $\begin{array}{l}\text { Kurumumuzda şuan için resmi anlamda Katılımcı bütçe uygulaması } \\
\text { yürütülmemektedir. }\end{array}$ \\
\hline G7 & $\begin{array}{l}\text { İl Özel İdaresinin bütçesi hazırlanırken gelin talepler incelenerek öncelik } \\
\text { sırasına göre değerlendirme yapılmaktadır. (İşin aciliyeti, maliyeti, faydası } \\
\text { gibi) }\end{array}$ \\
\hline G8 & $\begin{array}{l}\text { Daha çok encümen üyeleri vasıtasıyla vatandaşın fikirlerinin alınması ve köy } \\
\text { muhtarları ile yapılan toplantılar aracılığıly kırsal kesimin talep ve } \\
\text { isteklerinin alınması gibi yollar izlenmektedir. Kırsal kesimin refahını } \\
\text { artırmaya yönelik hizmet ve yatırımlara önceli verilmektedir. Ayrıca stratejik } \\
\text { plan ile belirlenen paydaş kurumları Yatırım Kartları üzerinden taleplerinin } \\
\text { alınması yoluyla bütçeleme faaliyetlerine katılımları sağlanmaya } \\
\text { çalışllmaktadır. Genel olarak vatandaş odaklı bir hizmet politikası } \\
\text { izlenmektedir. Valilik bünyesinde vatandaşla en üst düzeyde iletişimin } \\
\text { kurulması, taleplerinin etkin ve hızlı bir şekilde alınarak takip edilmesi ve } \\
\text { sonuçlandırılması amacıyla "Açı Kapı Milletin Kapısı" adı altında beyaz } \\
\text { masa projesine benzer bir birim kurulmuştur. }\end{array}$ \\
\hline G9 & $\begin{array}{l}\text { Kurum stratejik planları ve faaliyet-performans programları ile Katılımcı } \\
\text { Bütçeye yönelik çalışmalar yapılmaktadır. Özellikle bunların başında kırsal } \\
\text { kesimde vatandaş ve muhtarlar ile yapılan toplantılarda belirlenen talepler } \\
\text { doğrultusunda halkın öncelikli ihtiyaçları yerinde tespit edilip bütçe } \\
\text { hazırlanmaktadır. }\end{array}$ \\
\hline G10 & $\begin{array}{l}\text { İlimiz köy muhtarları köylerin ihtiyacı olan hizmetleri İdaremizden talep } \\
\text { etmekte uygun bulunanlar için bir sonraki yıl bütçeye ödenek konulmaktadır. }\end{array}$ \\
\hline G11 & $\begin{array}{l}\text { Uşak İl Özel İdaresi Katılımcı bütçeye yönelik yıllık ihtiyaçlar ve talepler göz } \\
\text { önünde bulundurularak gelecek yılların buna yönelik hizmet politikaları } \\
\text { geliştirilmeye çalışılmaktadır. }\end{array}$ \\
\hline
\end{tabular}

Soruya verilen yanıtlar incelendiğinde Uşak il özel idaresinin özellikle bir strateji belirlemediği görülmektedir.

G6 görüşmeci ise, şuanda katılımcı bütçe uygulamasının olmadığını belirtmiştir sadece 2007 yılında uygulandığını belirtmek istemiştir.

\section{Soru 6: Uşak İli Katılımcı Bütçe çalışmasında STK’lerin ve vatandaşların bütçe sürecine ilgisi ne düzeydedir?}

Altıncı soru ile birlikte Uşak İl özel idarisinde katılımcı bütçe uygulamalarında STK ve vatandaşların ne derecede ilgi gösterdikleri sorulmuştur ve bu soru ile katılım oranları görülmek ve ortaya konulmak istenmektedir. Bu soruya verilen cevaplar ise Tablo 7'de gösterilmektedir. 
Tablo 7. Uşak İli Katılımcı Bütçe Çalışmasında STK’lerin ve Vatandaşların Bütçe Sürecine İlgisi Ne Düzeydedir?

\begin{tabular}{|c|c|}
\hline $\begin{array}{l}\text { Katılımcı } \\
\text { Kodu }\end{array}$ & Katılımcı Cevabı \\
\hline G1 & $\begin{array}{l}\text { STK'lerin hiçbir katkısı yoktur. Vatandaşların doğrudan bir ilgisi söz konusu } \\
\text { değildir. Köy yardımları muhtarların ilgi ve alakası ile doğru orantılıdır. Aktif } \\
\text { rol oynayan muhtarların yatırımları ön planda tutuluyor. Köy yardımları } \\
\text { muhtarların orantısız baskısı ile adaletsiz dağıtım rol oynamış oluyor. }\end{array}$ \\
\hline G2 & $\begin{array}{l}\text { Sivil Toplum Kuruluşlarının gerek İl Özel İdare'de gerekse de belediye } \\
\text { bütçelerinde etkin rol aldıklarını düşünmüyorum. En azından Uşak'ta aktif } \\
\text { değiller ve bu yönde eksiklik görüyorum. Kendi alanlarının çok fazla çerçevesini } \\
\text { doldurarak hizmet yapabildiklerini düşünmüyorum. Bana göre yapılacak } \\
\text { hizmet ve yatırımların önceliğinin belirlenmesi noktasında Sivil Toplum } \\
\text { örgütlerinin ciddi mana da etkin olması gerekiyor. Ancak uygulamada } \\
\text { STK'lerin ve vatandaşların her ne kadar bütçeye olan ilgisi etkin olmasa da yerel } \\
\text { anlamda köy muhtarlarının kendi yatırımlarının bütçeye alınması noktasında } \\
\text { ciddi bir faaliyetleri ve çabaları söz konusudur. Özellikle olaya köyler olarak } \\
\text { bakacak olursak katılımcı bütçe çalışmasına ilişkin köylerde muhtarlar işin } \\
\text { bilincinde olduğu için aktif bir rol alıyorlar ve etkili projeler sunmaya } \\
\text { çalışıyorlar. }\end{array}$ \\
\hline G3 & $\begin{array}{l}\text { Genel olarak bütçeleme faaliyetlerine halkın ve STK'lerin ilgisi azdır. Bu konuda } \\
\text { düzenli çalışmalar yapılmalı örneğin; imar planları konusunda STK'lerin ve } \\
\text { paydaş kurumların görüşlerinin alınmasını oldukça önemli olduğunu } \\
\text { düşünüyorum. Ama genel olarak vatandaş ve STK'lerin bütçeleme süreçlerine } \\
\text { katılımı düşüktür. }\end{array}$ \\
\hline G4 & $\begin{array}{l}\text { Bugüne kadar bir çalışmaya diyorsanız, hazırlanan projelere halkın ihtiyacına } \\
\text { uygunsa ilgisi üst düzeyde doğrudan halkın talepleri var. Hayvan içme suyu } \\
\text { projesi en çok ilgi görüyor. }\end{array}$ \\
\hline G5 & $\begin{array}{l}\text { Genel anlamda her şey Devletten bekleniyor, talep edilen yatırım ve hizmetleri } \\
\text { yerine getirilmesi fazla maliyet gerektirmesi halinde STK'lerin ve vatandaşlar } \\
\text { tarafından bu duruma sıcak bakılmıyor. Bu nedenle Sivil toplum örgütlerinin ve } \\
\text { vatandaşların bütçe oluşturulma sürecine olan ilgisini az olduğunu } \\
\text { düşünüyorum. Vatandaşların katılımı çok düşük katılımın artmasından } \\
\text { yanayız. Biz özel idare olarak yatımı ve hizmetlerde vatandaşın talebi varsa } \\
\text { önceliği var prensibi ile hareket ediyoruz ve bütçe de katılımcılığı sağlamak } \\
\text { amacıyla özellikle köylerin hizmet ve projelerini daha ön plana alıyoruz. }\end{array}$ \\
\hline G6 & $\begin{array}{l}2007 \text { yılında "Yerel Yönetim Reformuna Destek Projesi” kapsamında pilot } \\
\text { projelerden birisi seçilen idaremizin katılımcı bütçe uygulamasına vatandaşların } \\
\text { ve STK’lerin katkısı beklenen düzeyde gerçekleşmiştir. }\end{array}$ \\
\hline G7 & $\begin{array}{l}\text { Katılımcı bütçe vatandaş ve STK'lerden çok muhtarlar aracılığıyla yapıldığından } \\
\text { bu ilgi düzeyinin ölçülmesi tam olarak mümkün olmamaktadır. }\end{array}$ \\
\hline G8 & $\begin{array}{l}\text { Vatandaşlar bütçenin ne olduğunu bilmedikleri için, bütçeleme faaliyetlerine } \\
\text { çok fazla bir katılım söz konusu değildir. Sadece ihtiyaçları olduklarında katılım } \\
\text { söz konusudur. Stratejik Planda yer alan paydaş sivil toplum kuruluşları dışında } \\
\text { STK'lerin bütçeleme faaliyetlerine katılımı sınırlı ve azdır. }\end{array}$ \\
\hline
\end{tabular}




\begin{tabular}{|cl}
\hline & $\begin{array}{l}\text { Daha çok paydaş kurumlar vasıtası ve muhtarlar aracılığıla bütçe } \\
\text { oluşturuluyor. } 2007 \text { yılında yapılan çalışmada vatandaş memnuniyetleri } \\
\text { doğrultusunda katılımcı bütçeye yönelik hizmet geliştirme eylem planları }\end{array}$ \\
& uygulanmıştır. $\mathrm{Bu}$ uygulamalar doğrultusunda vatandaşların öncelikli \\
& ihtiyaçları belirlenmiştir. Bu açıdan halkın katılımcı bütçe oluşturmaya yönelik \\
& ilgisinin olduğunu düşünüyorum. STK ler kendi faaliyet alanlarını ilgilendiren \\
& konularda katılım sağlamaktadırlar. \\
\hline G10 & Direkt vatandaşın katılımından bahsetmek mümkün değildir. \\
\hline & Uşak il Özel idaresindeki katılımcı bütçe çalışmalarında vatandaşve sivil toplum \\
& kuruluşlarının çok ilgili olduklarını düşünmüyorum. Bunu kurum bazında \\
& düşünürsek o kurumla ilgisi olan belirli kesimlerin katılımı sağlanabilir.
\end{tabular}

$\mathrm{Bu}$ soruya görüşme yapılanların genel olarak ayni Cevabı verdiği görülmektedir. Vatandaşların ve STK'ların katılımcı bütçe uygulamasına ilgi göstermedikleri belirtilmiştir. Vatandaşların bütçelemeyi bilmediği beyan eden görüşmeci, STK’larında çok önemsemediğini belirtmiştir. Bu cevaplardan çıkan sonuç ise, katılımcı bütçe uygulamasının Türkiye'de çok yeni bir kavram olduğu ve birçok kişinin bilmediği göz önüne alınırsa, vatandaşların ve STK'larında bu kavram hakkında bilgilendirilmesi gerektiği ortaya çıkmaktadır.

\section{Soru 7: Uşak İl Özel İdaresinin katılımcı bütçe uygulamasına ait alt yapı oluşturacak birimleri nelerdir ve nasıl çoğaltılabilir?}

Yedinci soru, Uşak İl özel idarisinde katılımcı bütçe uygulamaları kapsamında birimler olup olmadığı ile ilgili soru sorularak, il özel idarenin katılımcı bütçe uygulamalarına nasıl hazırlandığı ortaya konulmak istenmektedir. Katılımcıların bu soruya verdikleri cevaplar ise Tablo 8'de gösterilmektedir.

\section{Tablo 8. Uşak İl Özel İdaresinin Katılımcı Bütçe Uygulamasına Ait Alt Yapı Oluşturacak} Birimleri Nelerdir ve Nasıl Çoğaltılabilir?

\begin{tabular}{|c|c|}
\hline $\begin{array}{c}\text { Katılımci } \\
\text { Kodu }\end{array}$ & Katılımcı Cevabı \\
\hline G1 & $\begin{array}{l}\text { Encümen toplantıları, Muhtarlar, İGM üyeleri çok önemli vatandaş } \\
\text { taleplerini esas alıyor. Yapılan alt yapı çalışmalarında belirli bir plan- } \\
\text { program yapılmaya çalışılsa da köyde baskın gelen grup tarafından bu } \\
\text { program değişiyor ve kara düzen diye tabir ettiğimiz düzene az miktarda da } \\
\text { olsa uyarak çalışmalarımızı sürdürüyoruz. Bunu tamamen değiştirmeye } \\
\text { çalıştığımızda sistemin tıkanacağı düşünülüyor. }\end{array}$ \\
\hline G2 & $\begin{array}{l}\text { Uşak İl Özel İdaresinin katılımcı bütçe uygulamasına yönelik alt yapı } \\
\text { oluşturacak birimlerin başında köylerde yapılan muhtarlar toplantısı } \\
\text { gelmektedir ve onlarla istişareler yaparak, yapılacak olan hizmet ve yatırımlar } \\
\text { belirlenmektedir. Bu kapsamda halkın istek ve taleplerinin yer aldığı yazılı } \\
\text { talep formları muhtarlar aracılığıyla kurumumuza bildirilmektedir. } \\
\text { Köylerde muhtarlar aracılı̆̆ıyla toplanan talepler öncelikle encümen } \\
\text { toplantısında görüşülüp Uşak İl Özel İdaresinin imkanları dahilinde } \\
\text { üzerinde mutabık kılınan hizmet ve projeler gerçekleştirilmek üzere bütçede } \\
\text { yer verilmektedir. Ayrıca } 2007 \text { yılında yerel yönetimlere destek reformu } \\
\text { kapsamında başlatılan katılımcı bütçe çalışması doğrultusunda kullanılan } \\
\text { yatırım kartları uygulaması ile kurumlardan toplanan talepler il özel idare }\end{array}$ \\
\hline
\end{tabular}




\begin{tabular}{|c|c|}
\hline & 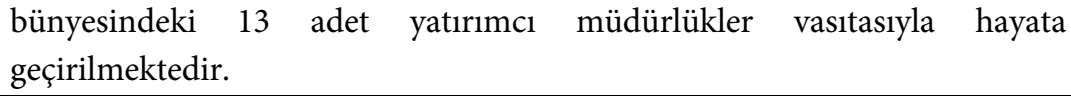 \\
\hline G3 & $\begin{array}{l}\text { Genel itibariye özel idare bünyesinde yer alan } 13 \text { adet müdürlükler vasıtası } \\
\text { ile ortak projeler yapılıyor. Ama katılımcı bütçeye yönelik çalı̧malar esas } \\
\text { olarak mali hizmetler müdürlüğu ve bütçe servisi tarafından } \\
\text { yürütülmektedir. Avrupa Birliği tarafından desteklenen ve ilimizde } 2007 \\
\text { yılında gerçekleștirilen katılımcı bütçe çalışmalarında Avrupa Birliği ve Dış } \\
\text { İlişkiler Müdürlüğü de önemli bir rol oynamıştır. }\end{array}$ \\
\hline G4 & $\begin{array}{l}\text { Birim müdürlerinin raporları, halktan gelen dilek ve istekler tespit edilip, } \\
\text { planlama noktasında yetkili birimlerin görüşleri, Beyaz masa projesi } \\
\text { uyarlanabilir. Sizin projeniz uygulaması uygulanabilir. }\end{array}$ \\
\hline G5 & $\begin{array}{l}\text { Yol su kanalizasyon, tarımsal şube, plan proje, imar ve çevre müdürlükleri } \\
\text { olmak üzere genel anlamda } 13 \text { adet müdürlük tarafından katılımcı bütçe } \\
\text { oluşturulmaya çalışıor. Özellikle yatırımcı müdürlükler vasıtası ile kırsal } \\
\text { kesimin talep ve istekleri yerine getirilmeye çalışılmaktadır. Köylere yönelik } \\
\text { yapılacak hizmet ve yatırımlarda Köy muhtarları etkin bir rol oynamaktadır. } \\
\text { Esas itibariyle Katılımcı bütçe uygulamasına alt yapı oluşturacak birim Mali } \\
\text { Hizmetler Müdürlüğü ve Bütçe Servisidir. Bütçe de ve stratejik planlarda } \\
\text { katılım arttırmak için il genel meclisi toplantılarına katılım teşvik } \\
\text { edilmelidir. Uşak Belediyesi tarafından uygulanan beyaz masa projesi ve } \\
\text { resmi internet sitesinde yer alana halkın talep ve isteklerini doğrudan } \\
\text { internet üzerinden başkana iletebildikleri "sizin projeniz" adlı uygulamalar } \\
\text { Uşak İl Özel İdaresince de uygulanabilir. }\end{array}$ \\
\hline G6 & $\begin{array}{l}\text { Mali Hizmetler Müdürlüğü-Bütçe Servisi'dir. Strateji Geliştirme Müdürlüğü } \\
\text { kurularak bu konuda daha ileri düzeyde çalışmalar yapılabilir. }\end{array}$ \\
\hline G7 & $\begin{array}{l}\text { Bu süreci takip edecek bütçe servisi vardır. Uygulamalı olarak takibi ise ilgili } \\
\text { müdürlükler tarafından yapılmaktadır. }\end{array}$ \\
\hline G8 & $\begin{array}{l}\text { Özel İdare bünyesinde yer alan } 13 \text { Müdürlük vasıtasıla Katılımcı Bütçe } \\
\text { uygulamasına yönelik çalı̧̧malar yapılmaktadır. Katılımcı Bütçe oluşturmaya } \\
\text { yönelik en önemli birim "Mali Hizmetler Müdürlüğü "dür. Katılımcı bütçe } \\
\text { uygulamasına ait alt yapı oluşturacak vatandaş talep ve istekleri ile uyumlu } \\
\text { bir bütçe oluşturmak için Strateji Geliştirme Daire Başkanlığı veya } \\
\text { Müdürlüğünün kurulması gerekir. Ayrıca Stratejik Planlarda katılımın } \\
\text { geliştirmesi ve paydaş sayısını arttırılması ve katılımcı bütçeleme tekniğini } \\
\text { geliştirilmesi amacıyla eğitim, seminer ve konferanslar düzenleyecek } \\
\text { birimlerin hayata geçirilmesi ve sivil toplum kuruluşları ile etkin bir işbirliği } \\
\text { gerekir. }\end{array}$ \\
\hline G9 & $\begin{array}{l}\text { Plan-proje, çevre koruma ve yol, su, kanalizasyon ve imar müdürlükleri başta } \\
\text { olmak üzere genel anlamda } 13 \text { yatırımcı müdürlük ortaklaşa çalışarak } \\
\text { katılımcı bütçe uygulamasına önemli hizmetler sunmaktadırlar. }\end{array}$ \\
\hline G10 & $\begin{array}{l}\text { Köylerde vatandaşlara yapılan toplantılarda ihtiyaçlar toplanmakta karar } \\
\text { verilen yatırımlar için bütçeye ödenek konulmaktadır. }\end{array}$ \\
\hline G11 & $\begin{array}{l}\text { Bütçe çalışmalarını yapan başta bütçe servisi olmak üzere diğer müdürlükler } \\
\text { Uşak İl Özel İdaresinin katılımcı bütçe uygulamasına ait alt yapı oluşturacak } \\
\text { birimleridir. }\end{array}$ \\
\hline
\end{tabular}

Katılımcı bütçe çalışmalarına yönelik özel bir birimin olmadığı, Uşak İl özel İdare bünyesinde bulunan müdürlüklerin bir araya gelerek çalışmalar yapıldığı görülmektedir. Bununla birlikte, genellikle kırsal ile ilgilenen il özel idarelerin köy muhtarları tarafından köy meydanlarında yapılan toplantılar sonucunda öncelikli çalışmaların belirlendiği görülmektedir. 
Sekizinci soru, Uşak İl özel idarisinde katılımcı bütçe çalışmalarının hangi seviyelerde yapıldığı görebilmek için görüşmecilere bu soru yöneltilmiştir. Katılımcıların verdikleri cevaplar çok tatmin edici düzeyde olmadığı görülmektedir ve direk cevaplar aşağıda verilen Tablo 9'da gösterilmektedir.

Tablo 9. Uşak İl Özel İdaresinin Katılımcı Bütçeye Yönelik Çalışmaları Hangi Düzeydedir?

\begin{tabular}{|c|c|}
\hline $\begin{array}{c}\text { Katılımcı } \\
\text { Kodu }\end{array}$ & Katılımcı Cevabı \\
\hline G1 & Katılımcı bütçe uygulamasına yönelik şu an yeteri kadar bilgiye sahip değilim. \\
\hline G2 & $\begin{array}{l}\text { Biz şuanda prensip olarak fayda ve maliyet analizi yaparak daha öncelikli olan } \\
\text { hizmet ve yatırımlara bütçede yer veriyoruz. Gerçekten faydası olmayan } \\
\text { çalışmalara öncelik vermiyoruz. Bu bağlamda katılımcı bütçeye yönelik } \\
\text { çalışmalar yerinde vatandaş odaklı olarak sürdürülmektedir. Özellikle bizim } \\
\text { açımızdan kırsal alanda yapılan muhtar toplantıları katılımcı bütçeye yönelik } \\
\text { çalışmalarımıza yön vermektedir. Bu çalışmalarda muhtar talep formları ve } \\
\text { yatırım kartları ile halkın gerçek ihtiyaçlarının yerinde tespit edilmesi } \\
\text { amaçlanmaktadır. Söz konusu hizmetler yerine getirilirken İl Özel İdaresinin } \\
\text { mali imkanları hizmetlerin önceliği ve aciliyetine önem verilmektedir. } 2007 \\
\text { yılında başlatılan katılımcı bütçe çalışmasının devamı niteliğinde olan bütçe } \\
\text { çalışmaları kısmen de olsa devam ettirilmeye çalışlmaktadır. Bu kapsamda } \\
\text { stratejik planda geniş bir katılım sağlamak için paydaşanalizi yapılarak içve dış } \\
\text { paydaşlar belirlenmekte ve katılımcı bir bütçe oluşturulmaya çalışılmaktadır. } \\
\text { 2007 yılında yapılan çalışmalarda yatırım önceliklendirme formu” ile } \\
\text { puanlama yapılarak kurumların yatırımlarının öncelik sırası ve önem sırası } \\
\text { belirlenmiş ve buna istinaden bütçe oluşturulmuştur. Ancak şuanda bu } \\
\text { uygulama devam ettirilmemektedir. }\end{array}$ \\
\hline G3 & $\begin{array}{l}2007 \text { yılında yapılan çalışmalar kısmen de olsa sürdürülüyor. Şu anda stratejik } \\
\text { plan hazırlanırken iç ve dış paydaş kurumlar belirlenip yatırım kartları } \\
\text { uygulaması ile yatırımlar önceliklendirilerek il özel idaresinin imkanları } \\
\text { dahilinde yerine getirilmektedir. Daha çok acil olan hizmet ve yatırımlara } \\
\text { öncelik verilmektedir. Köylere yönelik yapılacak hizmet ve yatırımlar köy } \\
\text { muhtarları ile yapılan toplantılarda görüşülmekte ve muhtar talep formları ile } \\
\text { köylerin ihtiyaç duydukları hizmet ve yatırımlar belirlenmektedir. Özel İdare } \\
\text { olarak kırsal kesime yönelik daha çok halkın talepleri doğrultusunda katılımcı } \\
\text { bütçeleme faaliyetleri gerçekleştiriliyor. Kırsal kesimde vatandaşlar taleplerini } \\
\text { muhtarlar aracllığıyla idaremize bildirmektedir. }\end{array}$ \\
\hline G4 & $\begin{array}{l}2020 \text { planlamanın teklif aşamasındayız. Ekim Ayı itibariyle katılımcı bütçenin } \\
\text { oluşturulması planlanıyor. }\end{array}$ \\
\hline G5 & $\begin{array}{l}\text { Uşak il özel idaresi katılımo bütçeye yönelik daha çok kırsal alanda hizmet } \\
\text { üretmekte ve kırsalı esas almaktadır. Şu anda katılımcı bütçe oluşturmaya } \\
\text { yönelik hizmet ve yatırımlar köylerin kalkınmasına ve gelişmesine yönelik } \\
\text { olup, yapılacak hizmet ve yatırımların kararı halkın sözcüsü konumunda olan } \\
\text { köy muhtarları ile birlikte alınmaktadır. Son dönemlerde vatandaşların } \\
\text { idaremizden talep ettiği hizmetlerin başında genellikle sosyal amaçlı hizmetler } \\
\text { gelmektedir. En çok talep edilen hizmet ise çok amaçlı toplantı salonlarıdır. }\end{array}$ \\
\hline G6 & $\begin{array}{l}2007 \text { yllinda pilot proje olarak uygulandiktan sonar tekrar kapsamlı bir } \\
\text { uygulama yapılmamıştır. }\end{array}$ \\
\hline
\end{tabular}




\begin{tabular}{|c|c|}
\hline G1 & $\begin{array}{l}\text { Köylülerimize malzeme temini yapıp imece usulü dediğimiz köy yardımlaşma } \\
\text { davranışı ile ihtiyaçlarını karşılasınlar ancak köylü işçilik olarak ta bunu bizim } \\
\text { karşılamamızı istediği için bu tamamlanamayan bir proje olarak kaldı. Köy } \\
\text { yardımları katılımcı bütçe uygulamasına yönelik bir hizmettir Kaşbelen } \\
\text { köyünde doğalgaz talebi nedeniyle imar planı yapıyoruz. Ağaçbeyli için de imar } \\
\text { planı yapıyoruz }\end{array}$ \\
\hline G2 & $\begin{array}{l}\text { Yol döşeme çalışmaları yapıyoruz. "Çok amaçlı salon gibi” çalışmalarımız var } \\
\text { bunu da belirlerken şunlara dikkat ediyoruz; bölgenin nüfus yoğunluğunu ve } \\
\text { bölgenin yaş oranı ve bölgenin büyüme oranı göz önünde bulundurularak } \\
\text { çalışma yapıyoruz. Bu veriler uygunsa bu çalışmaları yapıyoruz. Taleplerin bize } \\
\text { ulaşmasındaki çalışmalarımız köylere gidip yerinde görmek oluyor çoğunlukla } \\
\text { da çalışmalarımız köylerle ilgili olduğu için köy muhtarları ile birlikte gidip } \\
\text { yerinde çalışma yapıyoruz. Bu projeye de şöyle diyebiliriz; yatırım müzakere } \\
\text { masası diye adlandırabiliriz. }\end{array}$ \\
\hline G3 & $\begin{array}{l}\text { Esas itibariye Özel İdarenin yapmış olduğu hizmet ve yatırımlar vatandaş odaklı } \\
\text { proje ve hizmetler olup vatandaşlar tarafından en çok talep edilen hizmet ve } \\
\text { yatırımlar şunlardır: Çocuk oyun alanları, imam evi, Kur’an Kursu Binası, Köy } \\
\text { Konağı, İçme suyu, Yol, Kanalizasyon, sosyal faaliyet niteliğinde yapılan çok } \\
\text { amaçlı salonlardır. }\end{array}$ \\
\hline G4 & $\begin{array}{l}\text { Köy içi parke döşeme, çok amaçlı toplantı salonu köyler arası asfalt, hayvan içme } \\
\text { suyu göleti içme suları arıtma tesisidir. }\end{array}$ \\
\hline G5 & $\begin{array}{l}\text { Katılımcı Bütçe Açısından vatandaş odaklı hizmet ve yatırımlarımız arasında; } \\
\text { - Tarımsal sulama için trafo hatlarının kurulması } \\
\text { - Köy ve tarla yolları için greyderlerin yakıt ücretlerinde katılım projesi, } \\
\text { - Örtü altı seracılığı } \\
\text { - Çok amaçlı salonlar } \\
\text { - Yol, içme suyu ve alt yapı hizmetleri, } \\
\text { - Çocuk oyun parkları, } \\
\text { - Köy konakları(Örneğin; Karakuyu'da yapılan çalışma) yer almaktadır. }\end{array}$ \\
\hline G6 & $\begin{array}{l}\text { Köylerimizde muhtarlar aracılı̆̆ıla idaremize bildirilen vatandaş talepleri } \\
\text { gerçekleştirilmektedir. (Yol, su, kanalizasyon yatırımları vb.) }\end{array}$ \\
\hline G7 & Yol, su ve kanalizasyon gibi alt yapı projeleri vardır. \\
\hline G8 & $\begin{array}{l}\text { İl Özel İdaresince daha önce sadece yol, su, kanalizasyon gibi alt yapı hizmetleri } \\
\text { yerine getirilirken, vatandaş odaklı Katılımcı Bütçe uygulamasına yönelik kırsal } \\
\text { kesime yürütülen çalışmalarda sosyal kültürel alanlara yönelik talepleri(çocuk } \\
\text { oyun grupları, çok amaçlı salonlar, köy konakları vb.) daha çok talep edilmeye } \\
\text { başlamıştır. }\end{array}$ \\
\hline G9 & $\begin{array}{l}\text { Genel anlamda tüm proje ve yatırımlarımız katılımcı bütçe uygulamasına } \\
\text { yönelik hizmetler olup tümünün ortak tarafı köylünün yani kırsal kesimin } \\
\text { refahını artırıcı hizmetler sağlanmaktadır. Daha çok katı atık toplanması ve alt } \\
\text { yapı hizmetleri vatandaş talepleri doğrultusunda gerçekleştirdiğimiz katılımcı } \\
\text { bütçe proje ve yatırımlarıdır. }\end{array}$ \\
\hline G10 & daklı bir çok yatırım ve projesi bulunmaktadır. \\
\hline
\end{tabular}


G11

Kurumumuzun bu yönde yatırım ve projeleri bulunmaktadır. Özellikle yatırımcı şube müdürlükleri vasıtasıyla katılımcı bütçe oluşturmaya yönelik ortaklaşa çalışmalar yürütülmektedir. Bunların en başında yol, su, kanalizasyon, içme suyu ve alt yapı çalışmaları ile imar ve tarım müdürlüklerinin proje ve yatırımları bulunmaktadır. Doğrudan kurumların ve köylerde muhtarların talepleri göz önünde bulundurularak bütçe oluşturulmakta hizmet öncelikleri tespit edilmekte ve bu yönde çalışmalar yapılmaktadır. Daha çok kırsal kesimin refahının yükseltilmesine yönelik hizmetler gerçekleştirilmektedir. Köylere yönelik halkın talep ve istekleri muhtarlar aracılı̆̆ıla kurumumuza bildirilmektedir. Muhtar talep formlarında yer verilen hizmetlerin öncelikleri tespit edilmektedir. $\mathrm{Bu}$ talep ve isteklerden gerçekleştirilen projelerin belli başliları şunlardır;

- Çok amaçlı toplantı ve düğün salonları

- Köy içi kilit parke taş döşeme hizmetleri, çocuk oyun grupları

- Köy içme suyu ve tarımsal sulama hizmetleri

- Katı atıkların yerinde toplanması projesi

Katılımcı bütçeye yönelik vatandaşa yönelik birçok projenin ve yatırımın olduğunu beyan eden katılımcılar, spesifik olarak örnek verdiklerinde genellikle yapılan hizmetlerin altyapı çalışmalarına yönelik yatırımlar ve projeler olduğu görülmektedir. Bununla birlikte öncelik olarak kırsal bölgelerin sorunlarına öncelik verildiği görülmektedir.

\section{Sonuç}

Günümüzde, bilgi toplumu ve küreselleşme kavramlarının popüler olduğu bir zaman diliminde, toplumların yönetim anlayışında bir değişiklik olmaması kabul edilmemektedir. Bu nedenle, kamu yönetimindeki büyük dönüşüm 1980’li yıllardan sonra yaşanmaya başlamıştır ve yönetim daha katılımcı, açı/ş̧effaf, hesap verebilir, yönetişim, verimlilik, tutumluluk gibi ifadelerin olduğu yeni yönetim modelleri benimsenmeye başlamıştır. Bugünün şartlarında, devletler ve toplumlar merkezi hükümet yapıları yerine yerel yönetim yapıları tercih etmektedir. Ancak, bu durum yerel yönetimlerin etkili ve verimli hizmetler üreten kurumlara dönüşmesi ile mümkündür. Bunun için yerel yönetimlerin demokratik değerlere dayanması son derece önemlidir.

Tam demokrasi ancak yerel yönetim kanallarının toplum yararına işlevsel hale getirilmesiyle sağlanabilmektedir. Yerel yönetimler, yerel olarak topluluklarla ilgili konularda kendileri için kararlar veren bir organizasyon türüdür. Vatandaşlar yerel yönetimlerde demokratik ilke ve davranış alışkanlığı kazanmaktadır. Özellikle yerel yönetimlerde katılım anlayışını uygulamak kolay olmamakla beraber, başarılı örneklerin var olduğu gerçeği de yadsınmamalıdır. Katılımcı bütçe sürecini başarılı kılacak faktörlerden biri şüphesiz, vatandaşlık önceliklerinin uygulanacak hizmetlere ne derecede yansıyacağı ve bu prosesin nasıl yürütüleceğidir.

Çalışma kapsamında vaka çalışması olarak ele alınan Uşak İl Özel İdaresinin Katılımcı bütçe uygulamasının elde edilen derinlemesine görüşmelerde katılımcılara dokuz soru yöneltilmiştir ve bu sorulardan ilk üç tanesi katılımcı bütçeleme ile ilgili iken, daha sonraki 6 soru ise Uşak İl Özel idare kapsamında yapılan katılımcı bütçeleme uygulamaları ile ilgilidir. Katılımcıların büyük çoğunluğunun katılımcı bütçeleme kavramı ile ilgili farkındalık düzeyinin olduğu görülmektedir. Uşak İl özel idaresi kapsamında yapılan çalışmaların ise, 2007 yılında pilot uygulama olarak yapıldığı fakat sonrasında bu uygulamaya kısmen devam edildiği belirtilmektedir. Halk ve sivil toplum kuruluşları katılımcı bütçelemeye çok dahil olmadıklarını belirtmişlerdir. Son olarak katılımcı bütçeleme çalışmalara kapsamında halka yönelik yapılan 
yatırım ve projelerde öncelikli olarak kırsal alanlar olduğu ve bunların altyapı çalışmaları olduğu söylenebilir.

Sonuç olarak, Uşak İl Özel İdaresi tarafından uygulanmaya çalışılan katılımcı bütçeleme çalışmalarının tamda istenildiği gibi uygulandığı söylenemez.

Çalışma kapsamında katılımcı bütçeleme ve etkinliği ile ilgili öneriler aşağıda sunulmaktadır.

- Kamu sektörünün dünyanın birçok ülkesinde daha etkin bir şekilde çalışması için devlet, düzenleyici ve denetleyici faaliyetlerde katılımcı bir anlayış benimsemelidir.

- Yerel yönetimlerin hizmet verdiği alanlarda rekabetçi piyasa yapısından yararlanması önemlidir.

- Yerel yönetimler daha fazla dinleyen katılımcı mekanizmalar oluşturmalıdır ve halkın yerel yönetimlerde karar alma süreçlerine dahil fazla dahil olmalılardır.

- Katılımcı bütçe uygulamalarının Türkiye'de yaygınlaşması için, dünyadaki örnekler ele alınarak, yerel yönetimlerin projeler ile halkı bu uygulamaya dahil etmeleri önemlidir.

Katılımcı bütçe uygulamaları merkezi yönetimden ziyade yerel yönetimlerde daha çok uygulama alanı bulmuştur. Katılımcı bütçeleme, yerel yönetim, sivil toplum ve özel sektör arasındaki bağlantıyı güçlendirmek, bölgesel politikalarda öncelik sırasına koymak, kamu kaynaklarının dinamik kullanımı ve kaynak dağıtımında verimlilik, hizmet sunumunda şeffaflığın artması ve katılımcı demokrasinin güçlendirilmesi için bir araçtır. Katılımcı bütçelemenin başarısı için ana kıstas, yurttaşların ve diğer iştirakçilerin sisteme en erken derecede dahil edilmesidir.

\section{Kaynakça}

Altıngöz Zarplı, S. (2017). Kamu Bütçelemesinde Yeni Bir Yaklaşım Olarak Katılımcı Bütçeleme: Türkiye'de Belediyelere Yönelik Bir Araştırma, Doktora Lisans Tezi. Eskişehir Osman Gazi Üniversitesi. Sosyal Bilimler Enstitüsü. Eskişehir.

Baha, H. (2016). An Introduction on Descriptive Analysis; Its advantages and disadvantages. Leuphana Üniversitesi, Yüksek Lisans Tezi. https://www.academia.edu/25307454/Title_An_Introduction_on_Descriptive_Analysis _Its_advantages_and_disadvantages, Erişim Tarihi: 18.08.2019.

Blandford, Ann (2013): Semi-structured qualitative studies. In: Soegaard, Mads and Dam, Rikke Friis (eds.). "The Encyclopedia of Human-Computer Interaction, 2nd Ed.". Aarhus, Denmark: The Interaction Design Foundation.

Cabannes, Y. (2004). Participatory budgeting: a significant contribution to participatory democracy. Environment and Urbanization, 16(1), 27-46.

Çobanoğullari, G., ve Yereli, A. B. (2017). Katılımcı Demokrasi ve Bütçeleme. Sosyoekonomi, 25(1), 109-127.

Dağlı, E. (2017). Yerel demokrasinin sağlanmasında katılımo bütçeleme: Bandırma ve Çanakkale belediyelerindeki yöneticilerin algısı. Yüksek Lisans Tezi. Balıkesir Üniversitesi Sosyal Bilimler Enstitüsü. Balıkesir. 
Ergen, Z. (2012). Yönetimden yönetişime: Katılımcı bütçeleme modeli. Maliye Dergisi, 163, 316-334.

Gergerlioğlu, U., \& Dibo, M. (2017). Avrupa ülkeleri ve Türkiye uygulamaları kapsamında katılımcı bütçeleme yaklaşımı. Elektronik Sosyal Bilimler Dergisi, 16(63), 1142-1154.

Hsieh, H. F., \& Shannon, S. E. (2005). Three approaches to qualitative content analysis. Qualitative Health Research, 15(9), 1277-1288.

Özen, A., \& Yontar, İ. G. (2009). Katılımcı Demokrasi Anlayışında Bütçeleme: Katılımcı Bütçeleme. Maliye Dergisi, 156, 280-293.

Sakınç S. ve Aybar Bursalığlu, S. (2014). Bütçelemede Demokratik Bir Değişim: Katılımcı Bütçeleme, Elecronic Journal of Vocational Colleges- May, 4(1), s. 1-10.

Sintomer, Y., Herzberg, C., \& Röcke, A. (2008). Participatory budgeting in Europe: potentials and challenges. International Journal of Urban and Regional Research, 32(1), 164-178.

Souza, C. (2001). Participatory budgeting in Brazilian cities: limits and possibilities in building democratic institutions. Environment and Urbanization, 13(1), 159-184.

Sześciło Dawid, (2015). Participatory Budgeting in Poland: Quasi-Referendum Instead of Deliberation, HKJU Croatian and Comparative Public Administration, 15(2), p. 373-388.

Taytak, M. (2019). Katılımcı Bütçe Anlayışının Üniversite Bütçeleri Açısından Uygulanabilirliği: Uşak Üniversitesi Üzerine Bir Araştırma. Maliye Araştırmaları Dergisi, 5(1), 115-129.

TEPAV (2007).İyi Yönetişim İçin Örnek Bir Model: Katılımcı Bütçeleme. Yönetişim Etütleri Programı. Türkiye Ekonomi Politikaları Araştırma Vakfı www.tepav.org.tr.

Yıldırım, A., \& Şimşek, H. (2016). Sosyal Bilimlerde Nitel Araştırma Yöntemleri.(10. Baskı) Ankara: Seçkin. 